Canadian University Music Review

Revue de musique des universités canadiennes

\title{
A Selection of Letters from Déodat de Séverac
}

\section{Elaine Brody}

Numéro 6, 1985

URI : https://id.erudit.org/iderudit/1014040ar

DOI : https://doi.org/10.7202/1014040ar

Aller au sommaire du numéro

Éditeur(s)

Canadian University Music Society / Société de musique des universités

canadiennes

ISSN

0710-0353 (imprimé)

2291-2436 (numérique)

Découvrir la revue

Citer ce document

Brody, E. (1985). A Selection of Letters from Déodat de Séverac. Canadian University Music Review / Revue de musique des universités canadiennes, (6), 284-292. https://doi.org/10.7202/1014040ar

(c) Canadian University Music Society / Société de musique des universités canadiennes, 1985
Ce document est protégé par la loi sur le droit d'auteur. L'utilisation des services d'Érudit (y compris la reproduction) est assujettie à sa politique d'utilisation que vous pouvez consulter en ligne.

https://apropos.erudit.org/fr/usagers/politique-dutilisation/ 


\title{
A SELECTION OF LETTERS FROM DÉODAT DE SÉVERAC
}

\author{
Elaine Brody
}

Twenty-five years ago, I wrote my doctoral dissertation on the life and piano works of Déodat de Séverac (1872-1921), a contemporary of Debussy and Ravel, widely honored in his lifetime but consigned almost to oblivion some forty years after his death. In the quarter century since I embarked on my efforts to bring him some of the recognition that was his due, two complete series of recordings of his entire piano oeuvre have been released; an Association of Friends of Déodat de Séverac has been established; a new biography is in the works; an earlier one by Joseph Canteloube, never before published, will soon be in print. For the last few years, his home town, St. Félix, has been the site of summer chamber music festivals; and soon, his birthplace will become a museum of memorabilia of the composer and his friends.

De Séverac produced a corpus of piano works that reveal his deep love of the countryside in southwestern France, near Spain. These pieces bear titles similar to those of Albéniz, whose assistant he was for a few years at the Schola Cantorum, the school established in Paris in 1890 by Charles Bordes (1863-1909) and Vincent d'Indy (1851-1931). They also contain some of the color and picturesque quality of Mussorgsky's Pictures at an Exhibition. But one hardly acquired fame through the composition of piano pieces, and like every other musician at the beginning of the century, Séverac recognized that to attain any kind of eminence would require the composition of at least one opera for Paris. He wrote not one but two in that genre: Le Coeur du moulin, produced in 1909 at the Opéra-Comique and Héliogabale, performed at the arena in Béziers in 1910.

In 1907, as a new graduate of the Schola, Séverac entered the mainstream of music and musicians in Paris and apparently was 
promised a performance of Le Coeur du moulin, an event that did not occur until two years later. After the successful outdoor performance of Héliogabale - fifteen thousand crowded into the arena to hear the opera - the French cellist and conductor Louis Hasselmans (1878-1957) determined to present a concert version at the Salle Gaveau in Paris, using several of the Cobla players from Céret (another town in the south of France, where Séverac lived for a time) to give the work an authentic folkloric air. Séverac's works met with considerable success and for a time he joined the ranks of celebrated musicians of his day.

But he was not happy. More and more Séverac sought the peaceful surroundings of his native village, St. Félix. A generous, jovial man, he preferred the tranquillity of Languedoc to the bustle of Paris, and he soon settled permanently in Céret surrounded by a group of artists that included Picasso, Frank Haviland, Stuart Merrill, Aristide Maillol, Georges Braque, Juan Gris, Marie Laurencin, André Salmon, Max Jacob, and the Greek expatriot Moréas. Several of them established residence in the town, which, for a time became known as the "Mecca of Cubism." Later Séverac began dividing his time between St. Félix and Céret.

Like many young composers, Séverac was concerned with obtaining appropriate performances of his works. "How do I get a performance?" he asked himself. "How do I get the best singers I need? What kind of involvements do these artists have that might prevent their participation in my work? Who can advise me?"

For answers to these questions, Séverac sought the advice of his teacher and friend Charles Bordes. Paul Poujaud, a lawyer who was a close friend of Debussy, also made himself available to the young man for suggestions and assistance. Moréas, (the pseudonym of Iannis Pappadiamantopoulos, 1856-1910), the first writer to use the designation "Symbolist," became another confidant. $\mathrm{He}$ and the critic Pierre Lalo (1866-1943) are among the correspondents to whom Séverac wrote during 1906 to 1911.

I recently acquired several of his letters at auction, and I thought they might interest readers. Except for the last one that rather touchingly describes Séverac's situation in the middle of World War I, all pertain to works or performances in Paris in the first decade of this century.

The first letters and postcards are written to Paul Poujaud. Bordes knew him well and called him by his first name (see letter of 17 January 1907); Séverac addressed him first formally and then informally as Cher ami. Except for the short note of 15 February 
1909, where Séverac writes to Moréas about Reynaldo Hahn, Proust's favorite musician friend, most other letters are to the editor of the review Musica. The last letter, in behalf of the woman director of the hospital where Séverac worked as an orderly during the last months of the war, is probably to Pierre Lalo.

Dear friend,

I just received a letter from $M$. Carbonne, regisseur of the OpéraComique, suggesting the tenor Sans (?) for the role of Jacques. I know nothing about this singer and if you can fill me in about him, I would be grateful.

As for Madame Carré, ${ }^{1}$ she would not be able to sing the "Coeur du M" [sic] because of "Chiquito," 2 Carbonne tells me.

If I understand properly, Madame Carré prefers the music of "Chiquito" to that of "Coeur du moulin" and she must have good reasons because Nouguès's [production ] ${ }^{3}$ it seems, was handsomely mounted -

I'm permitting myself to come and ask you your advice not on the subject of $M$. Nouguès's music, because I'm familiar with it, but on the subject of the tactics to take with regard to Carré.

Should I insist on having Marguerite Carré, whom the offical communiqués from the Opéra-Comique have designated as the future creator of "Coeur," or must I simply give in to her new desire to not perform [in my piece]?

In that case, I intended to ask for Mlle Vautrin or Mme Merentre. What do you think of that?

You would be very kind to give me your advice before I reply to Mme Carré and I thank you in advance for your understanding and your trouble.

If I but hearkened to my own nature, I would say the devil with it all and content myself with addressing Carré with the sonorous word of King Ubu, seasoned with Languedocien garlic.

It's really awful to busy oneself with this nonsense when the weather is beautiful and the thrushes are intoxicated in the vineyards!

Again thanks, dear friend, very cordially yours with all my soul. 
My dear Paul,

Two words to tell you of yesterday's success. The hall was totally filled and on average receipts of more than 3000 francs and enormous success. The orchestra was thrilling, the great Lanson transcendental. He is truly a grand singer of the great school. His damnation aria was admirable and my little English horn played his part like in a Handel concerto, in astonishing fashion. It's a Gilot that is sprouting. D'Indy's suite also went well. In sum, it was a marvelous program despite its seeming incoherence. The Schola sang "O vos omnes" admirably. I'm not telling you much more about it, relinquishing my pen to D.D. who is always a delightful host.

Thousand Regards,

Charles [Bordes]

Dear Sir,

The good Pater yesterday did a fine job, from every point of view. If he were able to give three or four concerts like that one every year, all would go well. His orchestra is progressing well and it currently has a lot of rather wonderful youngsters and "winds."

What a pity that you could not come to this delightful town that you nevertheless love so much.

But I hope that if Bordes can realize his new and magnificent project, you will come - What a beautiful project! ${ }^{4}$ But how difficult! Happily, Bordes will succeed because he wants to. What beautiful faith! What touching audacity!

I will return soon to Paris with a new work in my trunk. It is not entirely finished and it's what is delaying my return. But it delays me a good deal to submit it to my friends.

I beg you to trust in my sentiments of lively affection and to accept my best wishes for 1907 .

Very cordially yours,

Séverac

\section{Dear friend,}

I don't know if you remember a conversation we had one evening at the Castéras ${ }^{5}$ on the subject of librettos for lyric dramas? You urged me to read certain books by Pouvillon ${ }^{6}$ that seemed to you in harmony with my music, "Antibels," among others.

The subject of this work which I have carefully read during vacation, the landscape where the action unfolds, the character of the people on 
stage (and whom I know well enough for having seen them daily) have in fact suggested to me the desire to fashion a musical drama from it.

It is on this subject that I want to ask your advice. It seems to me that in this plot, which I understand very well, certain alterations would be necessary or rather it would have to be enormously condensed. As it is now, I believe, this work is perceptibly too long.

I allow myself to come to ask you your feeling on this subject because - if I don't offend your modesty - I have great confidence in your taste.

Pouvillon's son, who is very intelligent, and my friend the poet Lafargue are at my disposal to do the alterations that I will deem necessary.

It is for that reason that I allow myself to come to ask you your advice as to the theatrical aspect of the work.

If you are willing to do this, you will fill me with joy and I will be very grateful.

Otherwise, if you are too busy to write to me, we will chat about it on my return to Paris (end of February).

Has Bordes spoken to you again about his theatrical project? This admirable dream will not be realized without great difficulties, and in the interest of this dear and great friend, he should not set sail without having a good compass in his pocket...

I am working a lot at this time on a short piece that I should like to complete before returning to Paris.

Will it be good?!! I wouldn't yet know, but you will see it.

Be kind enough to remember me to my friends the Scholistes and believe in my warm and very sincere friendship.

Séverac

[Postcard to Paul Poujaud

13 rue Solferino Paris]

I was delayed, dear friend, in telling you how much pleasure I received from your lovely card.

I'm lazy, half speechless ... but I don't forget my friends.

All [the best] to you

Séverac 
[Pneumatique to Poujaud]

Dear Sir and friend,

I'm again taking advantage of your kindness. Would you give me the address of M. Lalo7 or ask him (if you have occasion to see him) if he has had a reply from Madame Bréval ${ }^{8}$ for Thursday.

In case she will not be able to do me the honor of singing at my concert, I would immediately have to make arrangements to have somebody else. Please excuse my offhanded manner and trust in my respectful sympathy.

Déodat de Séverac

[32 Denfert-Rochereau written on the side]

[To Jean Moréas

42 Avenue d'Orléans

Paris

Date postmarked is 15 February 1909]

Dear Master,

I was going to treat myself to going with you to applaud Raynaldo Hann [sic], but I must give up the pleasure.

I am, in fact, obliged to go and rehearse one of my interpreters.

Be kind enough to excuse me, dear Master, and trust in my lively and respectful affection.

Séverac, 11 rue d'Assas

Dear friend,

In the letter in which you asked me for a piano piece that I sent you, you said that the journal "Musica" would send me remuneration of a hundred "bucks," if I dare express myself in this way. Inasmuch as I've received nothing, I wonder if the package from "Musica" could have gone astray?

You would be very nice to fill me in on that matter because I sense that this traitoress called "the spineless woman" is lying in wait for me...

"Le Coeur" is going well at the Opéra-Comique. I hope that it will be done next week unless things go awry, which is always possible.

Pardon the liberty I have taken in this request and trust in my devoted and affectionate sentiments.

D. de Séverac, 11 rue d'Assas, Paris. 
Dear Sir,

I realized that I have had several distractions this afternoon. Since you were nice enough to name several of our comrades from Céret, I have forgotten to give you the name of Cortie, a remarkable fiddler, a musician like Manyach (already mentioned) who came with their group to take part in Paris in the performance of "Héliogabale". The success of these instrumentalists was really considerable.

Add also - if you have room left - J. Delcroze Urenea and P. de Montredon who also ply their trade with us!!!

Thanks and a thousand apologies, Your grateful

Séverac

\section{St. Félix near Castelnaudary}

Dear friend,

Here is the little [musical] autograph you requested. Is it OK? Certainly! I will be delighted that you are going to publish in "Musica" what you wish from my "Héliogabale."

Ask for it at Rouart, who published it, and above all, ask him for the corrected score by LeFlem, ${ }^{9}$ because the one that appeared is chock full of mistakes.

A thousand regards from your devoted Séverac

P.S. You could, perhaps, present a fragment of the ballet in the third act...

[My] friend,

I mailed you the promised piece. I also sent another. That one was too complicated!

So I sent you an unpublished piano piece [not new] but an older one. It will perhaps interest your readers to see what I've become while ageing.

[I shake] both hands.

Séverac, 11 rue d'Assas 
St. Pons Hérault 30 August 1916

Dear Sir and friend,

I wrote you over two weeks ago but I suppose that this letter must, like so many others, have gone astray. Here I go again coming to you with the same motive.

I want, a second time, to present you (in writing and it's too bad you can't see her with your own eyes) Madame Vauvillier, to whom our dear Bordes was a spoiled and coddled friend, as he deserved to be.

Madame Vauvillier would like to submit to you a musical work of which she is the author. She knows, Bordes having told her a thousand times, of your sound good taste and she would eagerly like your advice, even more so because she intends to present this work to the OperaComique. From that point of view, you would be able to give her excellent advice, and I am certain that the originality of this piece will be of great interest to you.

It would be necessary therefore that you hear the work by Mme Vauvillier, but you will certainly not be able to come to St. Pons. Also, Madame Vauvillier requested that I ask you if you would be able to receive her either at Guéret or at Paris when and where it would be possible for you [to do so].

I thank you in advance for your reply which I hope will fufill the wishes of the author of the "Eyes of the soul."

As for me, I am still an orderly in the hospital of St. Pons which is as a matter of fact under the loving care of Madame Vauvillier. Where will future events leave me? I don't know, but I put myself in the hands of Fortune.

I know nothing of the comrades (or very little), nothing about Alquier, the Castéras, the Master. Finally, when will it be over?

Thousand good regards, very affectionately, your devoted

D. de Séverac

P.S. Be kind enough to put your name on the envelope. Again thanks. 


\section{NOTES}

1. Marguerite Carré (1880-1947), a French soprano, made her debut as Mimi in 1899 at Nantes, where her father was director of the theater. Two years later, she appeared in Paris at the Opéra-Comique, and the following year married its director, Albert Carré. She created fifteen roles at the Opéra-Comique and continued singing until 1923, when she turned her attention to teaching. She divorced Carré in 1924.

2. Chiquito, a 4-act opera by Jean Nougès (see note 3) to a libretto by Henri Cain, describes scenes from Basque country life. The hero Chiquito is a pelote player; pelote is a Basque tennis game. The opera, first performed at the Opéra-Comique in 1909, is dedicated to Pierre Loti. Madame Carré sang the soprano lead. (See Henri de Curzon's article on the opera in Le Guide musical, 7 November 1909).

3. Jean Nougès (1875-1932) is best known for his opera Quo vadis, also to a libretto by Cain. First performed at Nice on 9 February 1909, it succeeded so well that on 26 November it was given at the Théâtre de la Gaïté in Paris. Based on the novel of 1895 by the Polish author Henryk Sienkiewicz (1846-1916), Quo vadis was performed at Antwerp, Prague, Vienna, Warsaw, and Moscow within a year and at Philadelphia, New York, and Milan the following year. Oscar Hammerstein opened his London Opera House on 13 November 1911 with a performance of this opera.

4. Charles Bordes (1863-1909), a pupil of César Franck, was a cofounder with Vincent d'Indy of the Schola Cantorum in Paris in 1890. Already in 1906 he made plans to create in France a practical theater for the revival of French operas of the seventeenth and eighteenth centuries.

5. René d'Avezac de Castéra (1873-1955), studied with d'Indy at the Schola from 1897 to 1907 , the same time that Séverac attended the school. $\mathrm{He}$ and his brother Carlos became close friends of Séverac. Some of their letters appear in Blanche Selva's short biography, Déodat de Séverac (Paris, 1930).

6. In 1907, Séverac started work on a lyric drama, Les Antibels, with a libretto by his friend, the poet Marc Lafargue. Les Antibels, based on a novel by Pouvillon, remained unfinished at Séverac's death.

7. Pierre Lalo (1866-1943), son of the composer Édouard Lalo, was a French music critic who wrote for the Journal des débats, the Revue de Paris, Le Temps, the Courrier musical, and Comoedia. On 18 April 1911, in Le Temps, he wrote a most favorable review of the Paris concert performance of Héliogabale.

8. Lucienne Bréval (1869-1935; real name Berthe Schilling), a mezzo soprano, made her debut at the Paris Opéra in 1893. From then until 1914, she was known for her roles in Wagnerian operas.

9. Paul LeFlem, born in 1881, still lives in Paris today. He, too, studied with d'Indy at the Schola Cantorum and became professor of counterpoint there in 1925. From 1924 to 1939 he also directed the singers of Saint-Gervais, a group founded in 1890 by Charles Bordes. 